Archives

of Animal Nutrition

Archiv

für Tierernährung

EDITORIAL BOARD

- K. Bođ̆a, Košice

S. Buraczewski, Jablonna

G. Burlacu, Bukarest

D. Demeyer, Gent

B. O. Eggum, Kobenhavn

G. Gebhardt, Leipzig

K.-D. Günther, Göttingen

A. Hennig, Jena

B. Juhász, Budapest

M. Kirchgeßner, Weihenstephan

W. Laube, Rostock

J. Leibetseder, Wien

K. H. Menke, Hohenheim

D. A. Melnitschuk, Kiev

L. P. Milligan, Edmonton

J. G. Morris, Davis

K. Nehring, Rostock

H.J. Oslage, Braunschweig

E. Pfeffer, Bonn

B. Piatkowski, Dummerstorf-Rostock

S. Poppe, Rostock

A. Rerat, Jouy-en-Josas

R. Schiemann, Rostock

N. A. Schmanenkov, Borovsk

A. Schürch, Zürich

R. H. Smith, Shinfield

A. Sommer, Nitra

S. Tamminga, Lelystad Grete Thorbek, Kobenhavn
FOUNDED BY

ERNST MANGOLD

EDITED BY

HANS BERGNER
VOLUME 37

1987 
Archives of Animal Nutrition covers the following topics: Biochemical and physiological foundations of animal nutrition with emphasis laid on the following aspects: Protein metabolism, metabolism of non-protein-nitrogen compounds, energy transformation, mineral metabolism, vitamin metabolism, nutritional effects and performance criteria, furthermore: practical animal feeding, feedstuff theory, feedstuff preservation and feedstuff processing.

We accept for publication:

Original manuscript not yet published in other journals and not intended for publication in other journals in the same form. Their length should not exceed 12 printed pages.

Manuscripts are to be sent to Prof. HANS BERGNER, Wissenschaftsbereich Tierernährung der Sektion Tierproduktion und Veterinärmedizin, Humboldt-Universität zu Berlin, Invalidenstr. 42, DDR - 1040 Berlin. We request the authors to submit their manuscripts typed double-spaced and ready for print. The institution which the paper originates will be mentioned together with the author's name in the title of the paper.

The author is requested to discuss and summarize the results of his work at the end of the manuscript.

Author's names in the manuscript are to be underlined with a red wavy line. We request you to underline italics with a black or blue wavy line. Small print is to be indicated by a black or blue vertical line on the margin. Bibliographic data in the text are given with the name of the author and the year of publication, in case of several publications in one year, a, b, c etc. are added according to the sequence of the publications in the bibliography, e.g. MEYER (1985 a). In the bibliography the papers are arranged alphabetically according to the name of the first author and quoted as follows: surname, first name, journal, volume, page and year.

Illustrations have to be restrict to the necessary minimum and to be enclosed separately. Indicative lines, letters etc. are to be entered in the pencil. For photographes, a cover sheet should be used for this. The captions of the illustrations are to be listed on an extra sheet.

The authors receive 50 special prints of their contributions free of charge.

\section{Terms of Subscription}

Orders for the journal "Archives of Animal Nutrition" can be sent

- in the GDR: to the Postzeitungsvertrieb or to the Akademie-Verlag Berlin, Leipziger Str. 3-4, DDR - 1086 Berlin;

- in the other socialist countries: to a book-shop for foreign language literature or to the competent newg-distributing agency:

- in the FRG and Berlin (West): to a book-shop or to the wholesale distribution agency Kunst und Wissen, Erich Bieber OHG, Wilhelmstr. 4-6, D - 7000 Stuttgart 1;

- in the other Western European countries: to Kunst und Wissen, Erich Bieber GmbH, General Wille-Str. 4,

- Ch 8002 Zürich;

- in other countries: to the international book- and journal-selling trade, to Buchexport, Volkseigener Außenhandelsbetrieb der DDR, Postfach 160, DDR - 7010 Leipzig, or to the Akademie-Verlag Berlin, Leipziger Str. 3-4, DDR - 1086 Berlin.

Zeitschrift „Archives of Animal Nutrition“

Herausgeber: Im Auftrag des Akademie-Verlages Berlin herausgegeben von Prof. Dr. Hans Bergner.

Verlag: Akademie-Verlag Berlin, Leipziger Str. 3-4, DDR - 1086 Berlin.

Ferpruf: 2236201 oder 22362 29, Telex-Nr.: 114420.

Bank: Staatsbank der DDR, Berlin Kंto-Nr.: 6836-36-20712.

Chefredakteur: Prof. Dr. sc. Hans Bergner.

Anschrift der Redaktion: Humboldt-Universität zu Berlin, Invalidenstr. 42, DDR - 1040 Berlin.

Veröffentlicht unter der Lizenznummer 1274 des Presseamtes beim Vorsitzenden

des Ministerrates der Deutschen Demokratischen Republik.

Gesamtherstellung: VEB Druckerei „Gottfried Wilhelm Leibniz‘, DDR - 4450 Gräfenhainichen.

Érscheinungsweise: Archives of Animal Nutrition erscheint jăhrlich in einem Band mit zwolf Heften.

Bezugspreis je Band 360,- DM (zuzüglich Versandspesen); Preis je Heft 30,-DM.

Der gültige Jahresbezugspreis für die DDR ist der Postzeitungsliste zu ențehmen.

Bestellnummer dieses Heftes: 1010/37

Urheberrecht: Alle Rechte vorbehalten, insbesondere die der Ubersetzung. Kein Teil dieser Zeitschrift darf in irgendeiner Form - durch Photokopie, Mikrofilm oder irgendein anderes Verfahren - ohne schriftliche Genehmigung des Verlages reproduziert oder in eine von Maschinen, insbesondere von Datenverarbeitungsanlagen verwendbare Sprache übertragen oder übersetzt werden. - All rights reserved (including those of translations into foreign languages). No part of this issue may be reproduced in any form, by photoprint, microfilm or any other means, nor transmitted or translated into a machine language, without written permission from the publishers.

(C) 1987 by Akademie-Verlag Berlin - Printed in the German Democratic Republic. 